\section{BLOOD GROUPS}

Les groupes sanguins chez les animaux

Individualités sanguine et tissulaire. Par R. Dujarric de la Rivière et A. Eyquem. (Collection de l'Institut Pasteur.) Pp. $407+2$ plates. (Paris: Éditions Médicales Flammarion, 1953.) 3,275 francs.

$\mathrm{B}$ LOOD-GROUP differences between individual goats were described by Ehrlich and Morgenroth in 1900 only a few months after Landsteiner's announcement of his discovery of the human blood groups. Ever since then, research on animal blood groups has continued and an enormous literature has been built up, scattered through very many journals and very varied in its methods and its aims, in contrast to the fairly well-integrated study of the human blood groups. Hitherto, almost the only comprehensive account of the subject has been a single excellent chapter in Wiener's "Blood Groups and Transfusion", so that a book bringing together the scattered threads has long been needed by workers in the field itself and in many related branches of science, especially, for purposes of comparison, by investigators of the human blood groups. That Dr. R. Dujarric de la Rivière and Dr. A. Eyquem have undertaken the task of reading and summarizing this vast literature entitles them to the gratitude of all such workers.

The title, "Les Groupes Sanguins chez les Animaux", as it appears on the outer cover, is supplemented on the title page by the words, "(Individualités sanguine et tissulaire)", and this extension of the subject to cover the whole of tissue immunity has involved the reading of another vast body of literature and has made the area covered so wide that no one or even two authors could possibly treat the whole of it critically.

Blood-group investigations require a knowledge both of serology and of genetics. The authors are primarily serologists, and the book is much sounder in its treatment of serology than of genetics. It is quite impossible for anyone to compress the whole of genetical thoory, as the authors have attempted, into eighteen pages in a way that will be useful as an introduction to the genetics of the blood groups. To those without a knowledge of genetics such an account is inadequate; to those with the knowledge it is unnecessary.

Because the human blood groups have been more thoroughly investigated than those of any of the lowor animals, an account of them is a necessary part of a book such as this; but it is the weakest part of the present book, containing numerous errors and statements of doubtful validity, especially on the genetical side. There is, for example, no evidence that (p. 64) the red cells of $L u^{a} L u^{a}$ individuals are more strongly agglutinated than those of heterozygotes; and the tabulation of the Lewis genotype $L e^{b} L e^{b}$ as corresponding to the phenotype Le $(a-b-)$ (p. 65) is contrary to the facts.

Most readers will, however, turn at once to chapter 5 on the blood groups of various animal species. It is disappointing to find that this central subject of the book is dealt with in only 90 out of a total of more than 400 pages. Nevertheless, nearly every investigation of any importance is adequately, if not critically, described. Of particular interest are the accounts of antigenic differences between different breeds of certain animals, especially sheep. On the other hand, the more difficult genetical topies are not so well treated, and the profoundly interesting subject of the linkage groups in cattle and some other animals, their similarities to and difforences from the human $R h$ system, deserves more space than it is given. There is a very good and comprehensive chapter on hæmolytic disease of the newborn among animals which will greatly interest comparative pathologists.

More than a hundred pages are devoted to the subject of tissue antigens, cytotoxic antibodies, and tissue grafting. The treatment appears on the whole to be adequate, but the reviewer is only familiar with a small part of this extensive field. It is surprising that only about four pages are devoted to a subject of such great practical importance as skin grafting.

A very valuable feature of the book is an alphabetical bibliography of some eight hundred entries. A number of these have been checked-some minor spelling mistakes were found but no errors in dates, volume numbers or pages. The bibliography includes most of the papers of first importance, but a vory considerable number of the works cited in the text are not included in the bibliography. Names, other than French, are very frequently misspelt in the text, but are mostly correct in the bibliography. There is a short but adequate general index.

Despite its faults, this book is an indispensable work of reference. It is most unlikely that in the near future anyone else will undertake the task of re-reading this immonse literature. It is almost inevitable that in a few years a now edition will bo needed. It is suggested that the authors should then omit the section (pp. 35-52) on general genetics, should call into collaboration a geneticist to ensure a more adequate treatment of the genetical and statistical aspects of the blood groups, should include in the bibliography references to all papers mentioned in the text, and should deal more fully with experimental skin grafting.

A. E. Mourant

\section{ELECTRON MICROSCOPY AS A TEXT-BOOK SUBJECT}

Introduction to Electron Microscopy

By Prof. Cecil E. Hall. (International Series in Pure and Applied Physics.) Pp. ix +451 . (London : MeGraw-Hill Publishing Company, 1953.) 64s. 6d.

THE final stage in the maturity of a branch of science or technology is the establishment of university lecture courses about it and the reduction of the sprawling, groping literature of its infancy to text-book form. By these standards electron microscopy has now come of age, as indeed the lapse of time since the invention of the first electron mieroscope would indicate. 'To gain entry to the McGrawHill International Series in Pure and Applied Physics adds the hallmark of respectability to a young and still somewhat revolutionary discipline.

The text now offered by Prof. C. E. Hall is based on his lectures to postgraduate studonts in biophysics at the Massachusetts Institute of Technology. It may be felt that it is much more detailed in its treatment of physical fundamentals than such a class would either understand readily or be likely to need in practising the subject. But the author has deliberately chosen such an approach, with an oye to probable future developments in the design of the instrument and in its operation. This is undoubtedly the wisest course to follow, although it will make the 